RHiNOLOGY

\title{
Bromelain's penetration into the blood and sinonasal mucosa in patients with chronic rhinosinusitis
}

\author{
Farmacocinetica della Bromelina nel sangue e nella mucosa rinosinusale \\ nei pazienti con rinosinusite cronica
}

\author{
D. PASSALI ${ }^{1}$, G.C. PASSALI ${ }^{2}$, L.M. BELLUSSI ${ }^{1}$, C. SARAFOLEANU ${ }^{3}, M^{2}$ LOGLISCI ${ }^{1}$, C. MANEA $^{3}$, C. IOSIF ${ }^{4}$, \\ F.M. PASSALI ${ }^{5}$ \\ ${ }^{1}$ ENT Department, University of Siena, Italy; ${ }^{2}$ ENT Section Catholic University of the Sacred Hearth, Rome, Italy; \\ 3 "Carol Davila" University of Medicine and Pharmacy, Bucharest, Romania; " "CESITO" Centre, "Sfanta Maria" \\ Clinical Hospital, Bucharest, Romania; ${ }^{5}$ ENT Department, University of Rome "Tor Vergata”, Rome, Italy
}

\section{SUMMARY}

The aim of this research is to investigate penetration of Bromelain into sinonasal mucosa in patients with chronic rhinosinusitis (CRS) versus a control group. Bromelain is derived from pineapple (Ananas comosus) and has various pharmacological effects. 40 patients (20 patients and 20 controls) were enrolled in the study. Bromelain $500 \mathrm{mg}$ tablet twice daily was administered for 30 days. We scored bromelain presence in turbinate and ethmoid mucosas and in the serum of both the groups. Bromelain has an excellent distribution from blood to rhinosinusal mucosa. Its diffusion ability may allow the use of bromelain as an anti-inflammatory agent in paranasal sinus pathologies.

KEY WORDS: Bromelain • Immunohistochemistry • Chronic rhinosinusitis

\section{RIASSUNTO}

Lo scopo di questa ricerca è quello di accertare la farmacocinetica di Bromelina nella mucosa rinosinusale e nel sangue in pazienti con rinosinusite cronica (CRS) ed in un gruppo di controllo. La Bromelina è un derivato dell'ananas (Ananas comosus) e dispone di vari effetti farmacologici. In questo studio sono stati arruolati 40 pazienti (20 pazienti e 20 controlli). Abbiamo somministrato Bromelina 500 mg in compresse due volte al giorno per 30 giorni. Abbiamo valutato la presenza di Bromelina nella mucosa dei turbinati e dell'etmoide e nel siero. La Bromelina risulta avere un'ottima distribuzione dal sangue alle mucose rinosinusali. In conclusione la capacità di diffusione può permettere l'uso di bromelina come farmaco anti-infiammatorio nelle patologie rinosinusali.

PAROLE CHIAVE: Bromelina $\bullet$ Immunoistochimica $\bullet$ Rinosinusite cronica

Acta Otorhinolaryngol Ital 2018;38:225-228

\section{Introduction}

We studied the penetration of bromelain into sinonasal mucosa in patients with CRS (group A) versus a control group (group B). Bromelain is derived from pineapple (Ananas comosus) and is a mixture of different substances, above all, proteolytic enzymes ${ }^{1}$. It is used in therapy for many problems and has various pharmacological effects, but its mechanism of action is still not completely clear. Several studies, carried out to determine its activity and effectiveness, have identified antithrombin, antioedema and fibrinolytic activity.

Clinical trials have shown that bromelain is useful for the therapy of several disorders such as chronic inflammation and autoimmune diseases ${ }^{2}$, particularly osteoarthritis and rheumatoid arthritis ${ }^{3-5}$. In vitro, it has demonstrated the ability to modulate the immune response to reduce the allergic reaction and to modulate macrophages, NK cells and $\mathrm{T}$ cells. It also increases the secretion of IL- $1 \beta$, IL- 6 and TNF $\alpha^{6}$.

In vitro and in vivo research suggests that bromelain may interfere with pathogens such as Vibrio cholera and Escherichia coli, whose toxins cause diarrhoea ${ }^{7}$.

Recent studies show that its administration before dental extraction can reduce the intensity of pain ${ }^{89}$.

Finally, in vitro studies highlight that bromelain has antitumoural activity, through an increase of concentrationdependent inhibition of cancer cell proliferation ${ }^{10}$. 


\section{Materials and methods}

We enrolled 20 patients (13 males, 7 females; 22-77 years) with CRS diagnosed according to the "International Consensus Statement on Allergy and Rhinology" 11 and EPOS criteria ${ }^{12} 13$ as group A and 20 patients ( 9 males, 11 females; 26-64 years) without sinonasal problems as group B.

We defined CRS as rhinosinusal inflammation lasting for more than 12 weeks and characterised by nasal obstruction, nasal drip (anterior and/or posterior), facial pain and alteration of smell. These symptoms had to be associated with other findings including positive nasal endoscopy for presence of purulent secretions or positivity for sinus inflammation on CT scan. Sinus mucosal inflammation is staged, according to Lund-Mackay score system ${ }^{14}$, as 0 (complete lucency), 1 (partial lucency) or 2 (complete opacity). The patients enrolled in group A belonged to Lund-Mackay Score grade 2.

This research was carried out with the ENT Dept. of Carol Davila University of Bucharest. All the patients had taken 1 tablet of bromelain $500 \mathrm{mg}$ twice a day by mouth for 1 month.

All patients signed informed consent. The Bucharest Local Health Unit Ethics Committee approved our research. Guidelines and requirements of the Declaration of Helsinki have been respected.

Exclusion criteria were: any other concomitant systemic/ topic drug treatment, presence of infections of other sites during all trials, hypersensitivity to any of the constituents of medication, pregnancy or lactation, hepatic or renal insufficiency ${ }^{15}$.

For group A, ethmoid and middle turbinate mucosa were taken during functional endoscopic sinus surgery. For group B, samples were taken during transnasal pituitary surgery.

Immunohistochemistry analysis was carried on according to procedures present in the international literature, considered as the most valid and reliable ${ }^{16}$.

Samples were washed for 30 seconds in $0.9 \%$ sodium chloride solution to minimise blood contamination, and then embedded in paraffin.

Paraffin sections were deparaffinised, rehydrated and rinsed in PBS, pH 7.4. Retrieval with cooking in specific buffer was raised in a microwave oven (Samsung) at $800 \mathrm{~W}$ for 5 minutes, and then $440 \mathrm{~W}$ for 10 minutes. The immunohistochemical method was an indirect twostage technique performed with a polymer based detection system (Max Polymer Detection System-Leica RE 7280-k) according to the manufacturer's instructions. All specimens were counterstained with Meyer's haematoxylin, examined and photographed with a Nikon E 200 microscope. Tissue sections were tested by immunohisto- chemistry using monoclonal antibodies against bromelain (Agrisera AB/AS09 552). The dilution used was 1:2000, cooked overnight at $60^{\circ} \mathrm{C}, 3 \% \mathrm{H}_{2} \mathrm{O}_{2}$.

We scored the quantity of bromelain present in samples of turbinate and ethmoid mucosa taken as grade $0,1,2,3$ and 4 based on the following:

- grade 0: no reaction;

- grade 1: positive reaction in $<25 \%$ of cells:

- grade 2: positive reaction in $25-50 \%$ of cells (Fig. 1);

- grade 3: positive reaction in 50-75\% of cells (Fig. 2);

- grade 4: positive reaction $>75 \%$ of cells.

A blood sample was taken and bromelain in blood was determined using the Western-blotting method. We scored the presence of bromelain in serum in:

- 0: no Bromelain;

- 1: optical density (OD) values of the migration gel $<60,000$;

- 2: OD values $60,000-80,000$;

- 3: OD values $80,000-90,000$;

- 4: OD values $>90,000$.

\section{Results}

The data collected are summarised in Table I. In Table I, for almost all enrolled subjects there was a good distribution of bromelain, from serum to nasal and sinus tissues. It is interesting to note that for 3 controls (group B), there was no distribution of bromelain either in serum or in rhinosinusal mucosa.

For patients, the distribution of bromelain between serum and turbinate tissue and between serum and ethmoid tissue was statistically significant ( $\mathrm{P}$ value of both: 0.0004 ). For control group, the $\mathrm{P}$ values were also significant ( $\mathrm{P}$ value of bromelain distribution between serum and turbinate tissue: 0.0356; $\mathrm{P}$ value of Bromelain distribution between serum and ethmoid tissue: 0.0207). Results of immunohistochemistry are shown in Figures 1 and 2.

\section{Discussion}

First of all, we can underline that the distribution of bromelain to serum and from serum to rhinosinusal tissues was higher in patients than in control.

Apart from the empirical results, there was important statistical significance, particularly for patients in group A. Thus, it can safely be stated that bromelain has an excellent distribution from serum to sino-nasal tissues, especially in patients with paranasal diseases. The results of controls (group B) were also statistically significant, even if this significance was less than in group A.

According to the International Rhinosinusitis Advisory 
Table I. Data collected.

\begin{tabular}{|c|c|c|c|c|c|c|c|}
\hline Group A & Serum & Turbinate & Ethmoid & Group B & Serum & Turbinate & Ethmoid \\
\hline 1 & 2 & 1 & 1 & 1 & 0 & 0 & 0 \\
\hline 2 & 1 & 2 & 0 & 2 & 2 & 1 & 1 \\
\hline 3 & 1 & 1 & 0 & 3 & 0 & 0 & 0 \\
\hline 4 & 3 & 1 & 1 & 4 & 0 & 0 & 0 \\
\hline 5 & 2 & 0 & 0 & 5 & 2 & 0 & 0 \\
\hline 6 & 3 & 2 & 2 & 6 & 1 & 1 & 1 \\
\hline 7 & 4 & 1 & 2 & 7 & 1 & 2 & 0 \\
\hline 8 & 4 & 2 & 1 & 8 & 2 & 1 & 1 \\
\hline 9 & 3 & 2 & 2 & 9 & 1 & 1 & 0 \\
\hline 10 & 2 & 2 & 2 & 10 & 2 & 2 & 2 \\
\hline 11 & 4 & 3 & 2 & 11 & 1 & 2 & 1 \\
\hline 12 & 2 & 1 & 0 & 12 & 1 & 0 & 1 \\
\hline 13 & 3 & 0 & 1 & 13 & 3 & 1 & 0 \\
\hline 14 & 2 & 2 & 3 & 14 & 1 & 0 & 1 \\
\hline 15 & 3 & 1 & 2 & 15 & 2 & 1 & 2 \\
\hline 16 & 4 & 2 & 3 & 16 & 2 & 2 & 1 \\
\hline 17 & 1 & 2 & 1 & 17 & 3 & 0 & 2 \\
\hline 18 & 3 & 3 & 2 & 18 & 2 & 1 & 2 \\
\hline 19 & 2 & 1 & 2 & 19 & 1 & 2 & 1 \\
\hline 20 & 3 & 0 & 1 & 20 & 3 & 1 & 1 \\
\hline
\end{tabular}

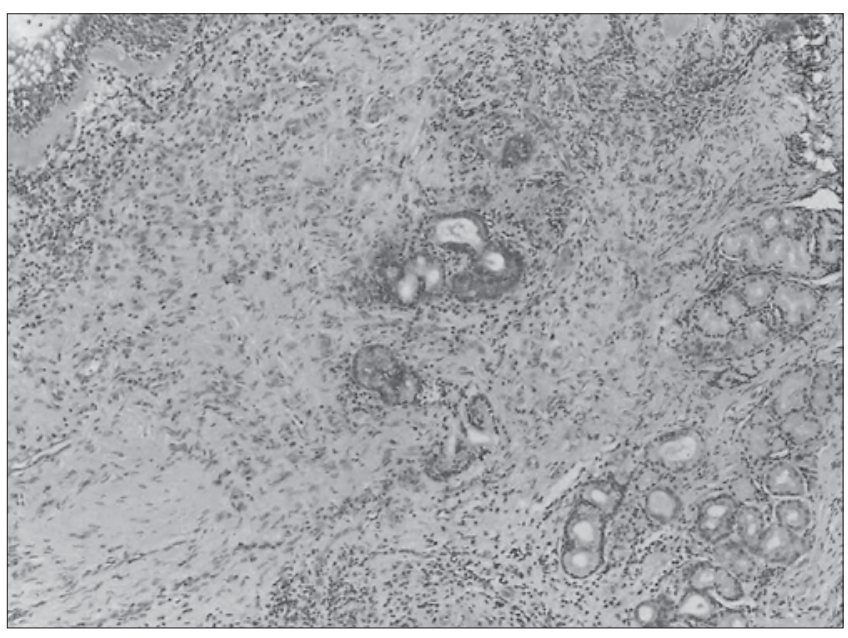

Fig. 1. Immunohistochemistry grade 1 positivity.

Board ${ }^{17}$, the goals of rhinosinusitis therapy are to treat the infection, shorten the disease and prevent recurrences; in order to achieve these goals, many different pharmacological approaches have been tested by several study groups. Acute rhinosinusitis (ARS) resolves without antibiotic treatment in most cases, symptomatic treatment and reassurance is the preferred initial management strategy for patients with mild symptoms. Antibiotic therapy should

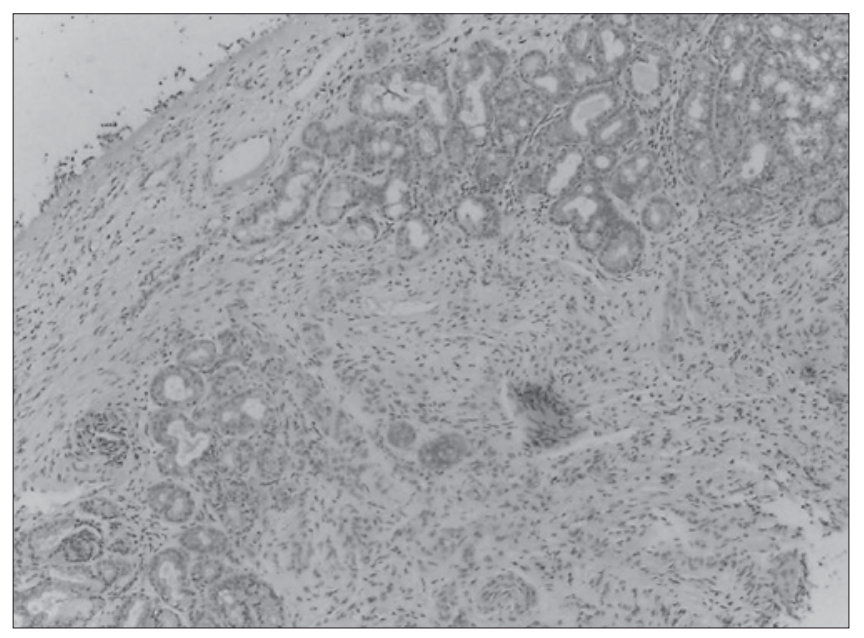

Fig. 2. Immunohistochemistry grade 2 positivity.

be reserved for patients with severe ARS, especially in presence of high fever or severe (unilateral) facial pain. Clinicians should weigh the moderate benefits of antibiotic treatment against the potential for adverse effects. The aim of a pharmacological approach in ARS is represented by the opening of the ostia, while in chronic inflammatory processes of the nose and paranasal sinuses the goal is to restore healthy respiratory mucosa. 
As already stated, bromelain has well-known effects such as antithrombotic, anti-oedema and fibrinolytic activity, and it is active as anti-inflammatory drug in chronic inflammation and/or autoimmune diseases ${ }^{3-5}$, reduction of allergic reaction, modulation of macrophages, NK cells and $\mathrm{T}$ cells and increase IL- $1 \beta$, IL-6, and TNF $\alpha$ secretion ${ }^{6}$. Considering these effects, the high concentration in CRS nasal cells we reported is good evidence of its strong potential in upper airways

These findings of the penetration of bromeline strongly call for confirmatory clinical trials in patients with CRS. In fact, the presence in tissue of a particular molecule, with known pharmacological effects, is the first step needed to continue with clinical studies.

\section{Conclusions}

Following our results, in the future it will be interesting to understand how distribution from serum to tissues is achieved, how it may be vary among patients and between patients and controls, and whether other modes of administration (for example intranasal administration) are equally effective or not.

Bromelain's ability of diffusion as an anti-inflammatory drug could be exploited in the treatment of nasal and sinus pathologies. The pharmacokinetics and pharmacodynamics characteristics of Bromelain and its safety profile could make it an option to achieve therapeutic results in CRS, thanks to its good tolerability and safety with no specific restrictions.

\section{References}

1 Bhattacharyya BK. Bromelain: an overview. NPR 2008;7:359-63.

2 Akhtar NM, Naseer R, Farooqi AZ, et al. Oral enzyme combination versus diclofenac in the treatment of osteoarthritis of the knee-a double-blind prospective randomized study. Clin Rheumatol 2004;23:410-5.13.

3 Mojcik CF, Shevach EM. Adhesion molecules: a rheumatologic perspective. Arthritis Rheum 1997;40:991-1004.

4 Cohen A, Goldman J. Bromelain therapy in rheumatoid arthritis. Pennsyl Med J 1964;67:27-30.
5 Leipner J, Iten F, Saller R. Therapy with proteolytic enzymes in rheumatic disorders. Bio Drugs 2002;15:779-89.

6 Barth H, Guseo A, Klein R. In vitro study on the immunological effect of bromelain and trypsin on mononuclear cells from humans. Eur J Med Res 2005;10:325-31.

7 Mynott TL, Guandalini S, Raimondi F, et al. Bromelain prevents secretion caused by Vibrio cholerae and Escherichia coli enterotoxins in rabbit ileum in vitro. Gastroenterology 1997; 113:175-84.

8 Tassman GC, Zafran JN, Zayon GM. Evaluation of a plate proteolytic enzyme for the control of inflammation and pain. J Dent Med 1964;19:73-7.

9 Tassman GC, Zafran JN, Zayon GM. A double-blind crossover study of a plant proteolytic enzyme in oral surgery. $\mathrm{J}$ Dent Med 1965;20:51-4.

10 Pavan R, Jain S, Shraddha, et al. Properties and therapeutic application of bromelain: a review. Biotechnol Res Int 2012;2012:976203.

11 Orlandi RR, Kingdom TT, Hwang PH, et al. International consensus statement on allergy and rhinology: rhinosinusitis. Int Forum Allergy Rhinol 2016;6 (Suppl 1):S22-S209.

12 Thomas M, Yawn BP, Price D, et al. EPOS Primary Care Guidelines: European position paper on the primary care diagnosis and management of rhinosinusitis and nasal polyps 2007 - a summary. Prim Care Respir J 2008;17:79-89.

13 Fokkens WJ1, Lund VJ, Mullol J, et al. European Position Paper on rhinosinusitis and nasal polyps 2012. Rhinol Suppl 2012;23:3 p preceding table of contents, 1-298.

14 Lund VJ, Mackay IS. Staging in rhinosinusitus. Rhinology 1993;31:183-4.

15 De Benedetto M, Passali D, Tomacelli G, et al. Penetration of prulifloxacin into sinus mucosa of patients undergoing paranasal sinus elective endoscopic surgery. J Chemother 2012;24:26-31.

16 Georgescu A, Stoicea M, Comănescu M, et al. Prognostic and predictive significance of the bcl-2/IgH translocation in malignant follicular lymphomas. Rom J Morphol Embryol 2010;51:687-91.

17 International Rhinosinusitis Advisory Board. Infectious rhinosinusitis in adults: classification, etiology and management. Ear Nose Throat J 1997;76(12 Suppl):1-22. 